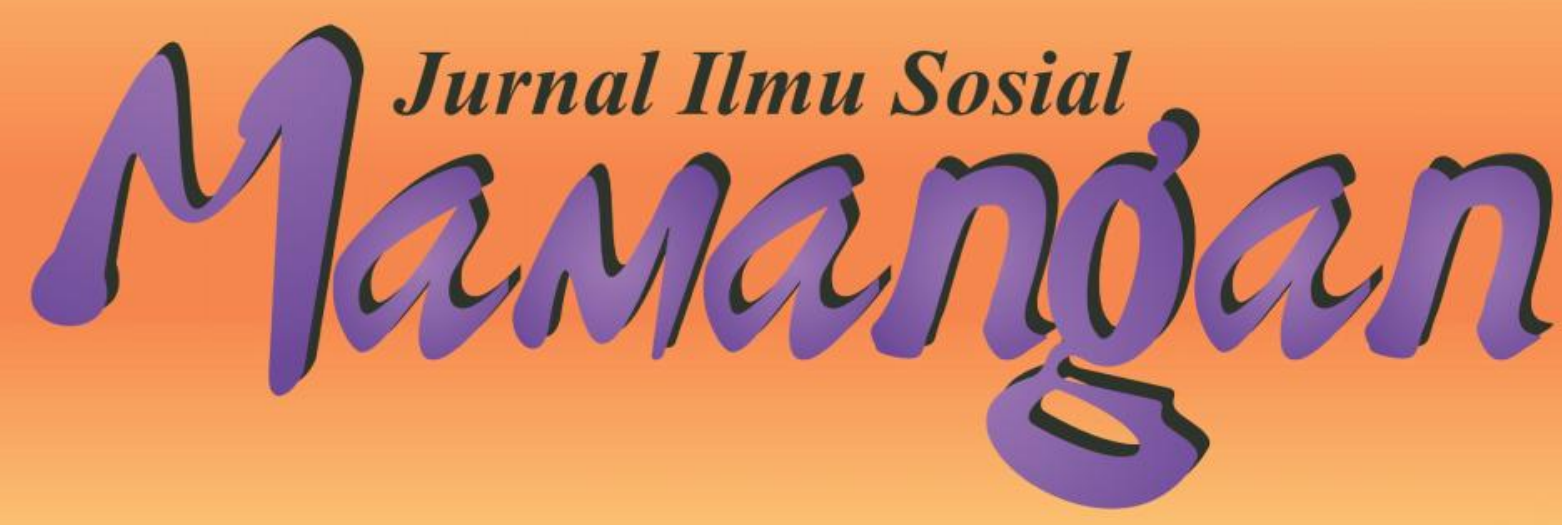

Kehidupan Sosial Ekonomi Petani Nilam Di Desa Taikako, Kec. Sikakap, Kab. Kepulauan Mentawai

YantiMurni, Ansofino \& Meldawati

Dampak Sosial Konflik Kinali 1999-2010

Welly Ibrahim, Ansofino \& Ahmad Nurul Huda

Pasang Surut Sosial Ekonomi Petani Cengkeh Di Nagari Koto Anau, Kec. Lembang Jaya, Kab. Solok 1960-2011

Yosefrizal, Sabar \& Witrianto

Perubahan Sosial Ekonomi Masyarakat Pasca Pengembangan Wisata Bahari Di Kepulauan Sikakap, Kabupaten Mentawai

IsmiAndriyani, Etmi Hardi \& Liza Husnita

Persepsi Masyarakat Petani Kelapa Terhadap Pendidikan Tinggi Anak Di Kecamatan Siberut Barat, Kabupaten Kepulauan Mentawai A. Tisnawati Tapondhadhai, Ansofino \& Ranti Nazmi

Kecendrungan Masyarakat Membeli Lahan Sengketa Di Kecamatan VII Koto, Kabupaten Tebo, Jambi

EsriEni Dewi Mukti, Slamet Rianto \& Dasrizal 


\section{Mitra Bestari}

Prof. Dr. Afrizal, MA. (FISIP, Unand Padang)

Dr. A. Latief Wiyata, M. Si. (Universitas Jember, Jember)

Prof. Dr. Badaruddin, M. Si. (FISIP, USU Medan)

Dr. Fikarwin Zuska, M. Si. (FISIP, USU Medan)

Nurus Shalihin, M. Si., Ph.D. (Fak. Ushuluddin IAIN Imam Bonjol Padang)

Dr. Semiarto A. Purwanto, M. Si. (FISIP, UI Jakarta)

Dr. Wahyu Wibowo, M. Si. (Universitas Nasional, Jakarta)

\section{Dewan Redaksi}

Dr. Zusmelia, M. Si.

Dr. Maihasni, M. Si.

Adiyalmon, S. Ag., M. Pd.

Firdaus, S. Sos., M. Si.

\section{Pemimpin Redaksi}

Firdaus, S. Sos., M. Si.

\section{Anggota Redaksi}

Dian Kurnia Anggreta, S. Sos., M. Si.

Rinel Fitlayeni, S. Sos., MA.

Surya Prahara, SH.

ISSN: 2301-8496

\section{Alamat Redaksi:}

Laboratorium Program Studi Pendidikan Sosiologi, STKIP PGRI Padang

Jl. Gunung Pangilun, Padang

Email: redaksimamangan@yahoo.com

Penerbit :

Program Studi Pendidikan Sosiologi, STKIP PGRI Padang

\section{Contac person :}

Firdaus (Hp. 085263881221/Email : daus gila@yahoo.com) 


\section{DAFTAR ISI}

Kehidupan Sosial Ekonomi Petani Nilam Di Desa Taikako, Kec. Sikakap, Kab. Kepulauan Mentawai

Yanti Murni, Ansofino \& Meldawati.

$60-72$

Dampak Sosial Konflik Kinali 1999-2010

Welly Ibrahim, Ansofino \& Ahmad Nurul Huda

Pasang Surut Sosial Ekonomi Petani Cengkeh Di Nagari Koto Anau, kec. Lembang Jaya, Kab. Solok 1960-2011

Yosefrizal, Sabar, Witrianto

Perubahan Sosial Ekonomi Masyarakat Pasca Pengembangan Wisata Bahari Di Kepulauan Sikakap, Kabupaten Mentawai

Persepsi Masyarakat Petani Kelapa Terhadap Pendidikan Tinggi Anak Di Kecamatan Siberut Barat, Kabupaten Kepulauan Mentawai

A. Tisnawati Tapondhadhai, Ansofino \& Ranti Nazmi.

Kecendrungan Masyarakat Membeli Lahan Sengketa Di Kecamatan VII Koto, Kabupaten Tebo, Jambi

Esri Eni Dewi Mukti, Slamet Rianto \& Dasrizal. 


\title{
DAMPAK SOSIAL KONFLIK ETNIK DI KINALI 1999-2010
}

\author{
Welly Ibrahim, Ansofino, Ahmad Nurhuda \\ Sekolah Tinggi Keguruan dan Ilmu Pendidikan (STKIP) PGRI Sumatera Barat
}

\begin{abstract}
Kinali is an area inhabited by diverse ethnic with different cultures, namely Minangkabau, Mandailings, and Java. The area consists of diverse ethnic, there is always the potential for conflict. The conflict in 1999 between ethnic Minang and Mandailing in the wake of misunderstanding between the two warring ethnic ie ethnic Mandailing ethnic Minang and eventually led to a major conflict anarchistic. The impact of the conflict in the district Kinali West Pasaman on society viewed from social and cultural factors that people prefer not to socialize and interact with other ethnic groups, the social and economic factors of conflict have an impact on the decrease in public income and region for post-conflict societies choose to not interact and one of which is not to the market. Social factors are political, namely the attitude of the ethnic Mandailing are not adaptive in the pattern of relationship with the dominant culture in Kinali caused by the attitude of discriminative ethnic Minang in Kinali against ethnic Mandailing in various facets of life which they live for these finally bear aversion to mambaur and mingle normal and reasonable.
\end{abstract}

\section{Keywords : Conflict, Ethnic Conflict, Socio-Economic Conflict}

\begin{abstract}
ABSTRAK
Kinali adalah daerah yang ditinggali beragam etnik dengan latar budaya yang berbeda, yakni etnik Minankabau, Mandailing, dan Jawa. Daerah yang terdiri dari beragam etnik, selalu ada potensi munculnya konflik. Konflik yang terjadi pada tahun 1999 antara etnik Minang dan etnik Mandailing di latarbelakangi karena kesalahpahaman antara kedua etnik yang bertikai yaitu etnik Minang dan etnik Mandailing akhirnya berujung ke konflik besar yang bersifat anarkis. Dampak dari konflik di Kecamatan Kinali Pasaman Barat terhadap masyarakat dilihat dari faktor sosial budaya yaitu masyarakat lebih memilih untuk tidak bersosialisasi dan berinteraksi dengan etnik lain, pada faktor sosial ekonomi konflik berdampak kepada terjadinya penurunan penghasilan masyarakat dan daerah karena pasca konflik masyarakat memilih untuk tidak berinteraksi dan salah satunya tidak kepasar. Faktor sosial politik yaitu sikap orang etnik Mandailing yang tidak adaptif dalam pola hubungannya dengan kebudayaan dominan yang ada di Kinali disebabkan oleh sikap deskriminatif etnik Minang di Kinali terhadap etnik Mandailing dalam berbagai segi kehidupan yang mereka jalani selama ini yang akhirnya berbuah keengganan untuk mambaur dan bergaul secara normal dan wajar.
\end{abstract}

\section{Kata Kunci : Konflik, Konflik Etnik, Konflik Sosial Ekonomi}

\section{PENDAHULUAN}

Pasaman Barat terletak di perbatasan (border line) antara Sumatera Barat dan Sumatera Utara. Sebuah daerah yang dikelilingi oleh perbukitan yakni Bukit Barisan serta Gunung Pasaman, Gunung Talamau, dan Gunung Merapi. Daerah ini boleh dikatakan merupakan "mini 
Indonesia". Sebab heterogenitas penduduk yang tinggi menempati daerah tersebut (Asnan, 2003) Kinali adalah salah satu kecamatan di Kabupaten Pasama Barat, Sumatera Barat, Indonesia. Kecamatan Kinali memiliki luas wilayah 365.57 km2 dengan jumlah penduduk sekitar 50. 271 jiwa, dan 8.804 Rumah Tangga atau KK yang terdiri dari 25. 722 laki-laki dan 24.548 perempuan (Badan Pusat Statistik Kabupaten Pasaman Barat 2010). Penduduk Nagari Kinali bersifat heterogen bila ditinjau dari latar belakang etnik budaya. Ada tiga asal usul etnik utama yang menempati daerah ini, yakni Minang, Jawa dan Batak/ Mandailing. Etnik yang ada di Kinali ada yang membentuk kelompok sendiri dalam srtian mereka tinggal pada jorong yang didalamnya terdapat hanya kelompok mereka dan ada pula yang berbaur dengan satu etnik lainnya.

Khusus untuk Jorong Sidomulyo merupakan pemukiman etnik Jawa yang penduduknya berasal dari bekas buruh kontrak perkebunan Ophir milik Belanda. Setelah masa kontrak habis sebagian besar dari mereka tidak pulang ke Jawa dan memilih tinggal di berbagai desa di Pasaman Barat, termasuk Nagari Kinali. Etnik Batak/Mandailing mendiami berbagai wilayah dalam di Jorong Ampek Koto. Etnik Batak/Mandailing di Kinali umumnya bekerja dalam usaha pertanian, ladang dan memelihara ternak. Mereka yang berasal dari Tapanuli Utara dan Tengah dan beragama Kristen kebanyakan ditemukan di Lapau Tampuruang, sementara yang berasal dari Tapanuli Selatan yang beragama Islam sebagian besar tinggal di Padang LapaiLapai dan Aia Putih. Pada table berikut dapat dilihat jumlah KK di Nagari Kinali menurut etnik yang ada.

Konsepsi sosial Minangkabau di Pasaman Barat membedakan penduduk atas dua kriteria yaitu penduduk asli (urang asa) dan penduduk pendatang (urang datang). Penduduk asli (urang asa) adalah orang yang terlebih dahulu mendiami suatu daerah, biasanya mereka dianggap golongan bangsawan. Mereka adalah orang yang merintis suatu daerah, mulai dari taratak kemudian berubah menjadi dusun, dari dusun menjadi koto dan akhirnya terbentuk nagari. proses semacam ini diistilahkan Kato dengan metamorfosa pemukiman.
Berbeda dengan penduduk asli (urang asa), penduduk pendatang (urang datang) merupakan mereka yang datang lebih kemudian dan statusnya dianggap lebih rendah dari penduduk asli )urang asa). Mereka sebenarnya dapat dibagi atas dua golongan, yang mempunyai ikatan keluarga dengan penduduk asli dan tidak mempunyai ikatan apa-apa dengan penduduk asli, golongan ini di anggap berada pada posisi lebih rendah dalam strata sosial Minangkabau.

Pada tahun 1930-an, ketika dunia dilanda depresi ekonomi. Depresi (krisis) ekonomi tersebut yang melanda dunia terasa juga pengaruhnya di Minangkabau. Kemiskinan semakin meresap dalam kehidupan masyarakat di Minangkabau. Untuk memenuhi kebutuhan hidup seharihari, masyarakat terpaksa menggadaikan harta benda mereka kerumah gadai (Mansoer, 1970). Kedatangan mereka sebagai penduduk pendatang, membuat resah orang Pasaman sebagai penduduk asli. Sebab mereka takut lahan hutan yang ada di kuasai oleh penduduk pendatang. Serta semakin mengecilnya kesempatan bagi penduduk asli untuk memiliki tanah yang seharusnya dipunyai oleh setiap anggota keluarga dalam satu keluarga. Dengan semakin mengecilnya tanah yang dimiliki oleh paraanggota keluarga akibat pembukaan hutan yang dilakukan oleh penduduk pendatang baik untuk lahan perkebunan maupun pemukiman membuat kemampuan ekonomi keluarga luas penduduk asli dalam menyantuni anggota keluarganya juga semakin berkurang.

Perbenturan yang terjadi kerena persoalan ekonomi dalam hal ini tanah memang suatu gejala yang bukan saja sekarang ini terjadi namun sudah lama merasuki kehidupan masyarakat kita. Gejala tersebut muncul tidak terlepas dari fungsi tanah itu sendiri. Bagi masyarakat Minangkabau misalnya, tanah bukan saja berfungsi ekonomi tapi juga sosial. Tanah bukan saja berfungsi sebagai tempat tinggal, sumber produksi atau pendapatan, tetapi juga mempunyai fungsi sosial dimana dengan tanah tersebut dapat mencerminkan kedudukan sosial dan status seseorang ditengah masyarakat atau dengan kata lain tanah sebagai dasar dari perbedaan sosial dalam masayarakat (Sjahmunir, 2001). 
Begitu pentingnya tanah ini dalam kehidupan masyarakat Minangkabau, sehingga tidaklah mengherankan seringnya muncul permasalahan seperti hal dalam kepemilikan tanah itu sendiri. Oleh karena itulah di daerah rantau MinangkabauPasaman, etnik Minang kabau sebagai penduduk asli menganggap etnik Mandailing telah merebut hak milik mereka atas tanah yang ada di daerahnya. Dalam perebutan tanah tersebut konflik yang mengarah kebentuk kekerasan tidak dapat dihindarkan. Sebagai sebuah konflik di satu sisi telah merusak tatanan kehidupan diantara etnik.

Renggangnya sistem kekerabatan, timbul kebencian, pengelompokkan pemukiman berdasarkan etnik sampai kepada usaha dibidang ekonomi yang tidak berjalan merupakan akibat yang ditimbulkan oleh adanya konflik tanah di Pasaman. Sebagai sebuah proses, konflik tersebut bukan semata-mata dalam kerangka konflik tanah saja namun telah menjalar ke persoalan lainnya bahkan sebagai pemicu untuk munculnya kearah bentuk kekerasan. Terjadinya konflik telah membuat kehidupan masyarakat tidak menentu. Rasa was-was muncul, bahkan rasa bencipun muncul.

Konfilk yang terjadi di Kinali pada beberapa tahun terakhir ini adalah konflik antar etnik Minang dan etnik Mandailing. Konflik yang terjadi antara etnik Batak Toba dan Mandailing berharap dengan etnik Minangkabau di Kinalai Kabupaten Pasaman meletus menjadi konflik besar pada Juli tahun 2000, dikatakan telah menjadi konflik besar karena telah bersifat anarkis dan merusak fasilitas-fasilitas umum. Konflik dipicu oleh beberapa faktor sehingga memunculkan kurangnya toleransi dalam hubungan antar etnik, pola interaksi yang cendrung disertai dengan kebencian dan dendam. Pola interaksi yang buruk yang di jalani selama ini sebenarnya disadari oleh masing-masing etnik tetapi tidak ada usaha untuk melakukan konsolidasi menjadikan hubungan yang ada menjadi lebih baik lagi. Maka konflik yang masih berupa ketidak sepahaman ini akhirnya pecah menjadi konflik kekerasan. Salah satu bentuk kekerasan yang di akibatkan karena konflik antar suku Minang dan Mandailing ini adalah pembakaran rumah penduduk etnik yang bertikai tersebut.

Konflik yang berkepanjangan selalu menyisakan ironi dan tragedi. Kekerasan yang terjadi dalam rentang waktu lama menjadikannya sebagai perilaku yang wajar dan bahkan terinstitusionalisasi. Akibatnya lingkaran setan kekerasan menjadi mata rantai yang semakin sulit untuk diputuskan. Karena perasaan masing-masing pihak adalah sebagai korban memicu dendam yang jika ada kesempatan akan dibalaskan dengan jalan kekerasan pula.

Dampak terbesar dari konflik adalah pada aspek sosial dan ekonomi masyarakat, dengan adanya konflik ini membuat masyarakat yang berada dilingkungan konflik merasa ketakutan, selalu was-was dan merasa tidak aman karena sewaktuwaktu mereka bisa menjadi korban penyerangan dan rasa curigapun selalu muncul dan karena konflik yang terjadi ini banyak masyarakat lebih memilih untuk tetap berada di rumah sehingga mengakibatkan aktifitas terhenti. Masyarakat yang biasanya pergi ke ladang mengurungkan niatnya untuk pergi keladang karena rasa takut tadi dan oleh karenanya berdampak kepada perekonomian masyarakat yang bertikai tersebut.

Berdasarkan kepada latar belakang di atas artikel ini bertujuan untuk membahas kondisi sosial ekonomi masyarakat yang terlibat konflik antar etnik. Artikel ini kan membahas kronoligis munculnya konflik antara etnik Minang dan Mandailing yang terjadi di Kecamatan Kinali Pasaman Barat, faktor-faktor yang mendorong terjadinya konflik etnik dan dampak sosial ekonomi konflik terhadap masyarakat yang terlibat konflik.

\section{METODE PENELITIAN}

Penelitian ini dilaksanakan di Kecamatan Kinali Kabupaten Pasaman Barat. Penelitian ini dilakukan berdasarkan metode sejarah yang dibagi kedalam empat tahap yaitu, pengumpulan sumber (heuristic) merupakan pengumpulan data untuk mendapatkan sumber primer maupun sekunder, dalam pengumpulan data dapat dilakukan melalui studi perpustakaan guna mencari data yang relevan, dan studi lapangan atau wawancara 
dengan pihak-pihak yang mempunyai peran dalam pengumpulan data. Kritik digunakan untuk melihat asli atau tidaknya sebuah sumber digunakan kritikan eksteren (otensitas sumber) dan untuk mengetahui keabsahan isi sumber tersebut dipakai kritikan interen (kredibilitas sumber). Interpretasi semua data yang telah didapat pada sumber-sumber primer maupun sumber-sumber sekunder, kemudian semuanya akan dikumpulkan kembali, faktor-faktor ini kemudian akan di interpretasikan untuk kemudian diungkapkan kembali menjadi penulisan sejarah deskriptif analitik. Historiografi penulisan ini menjelaskan semua hasil dari penelitian yang berupa sebuah karya sejarah yang berbentuk skripsi.

\section{ANATOMI KONFLIK DI KINALI}

Etnik Minangkabau pertama kali menempati daerah kinali, setelah itu datanglah orang dari Tapanuli Selatan beretnik Mandailing, awal kedatangan mereka tidak terlepas dari munculnya gerakan Paderi, memasuki abad ke 19 di Minangkabau. Sebuah gerakan yang menyerukan "kembali ke syariat Islam" yang berdasarkan Al-Quran dan Hadist Nabi Muhammad SAW. Dalam rangka mendakwahkan ajaran tersebut, Tuanku Rao, Tuanku Tambusai, Bagindo Usman melakukan penyebaran ajaran tersebut ke daerah Tapanuli Selatan. Diikuti pula dengan proses pengislaman serta menguasai daerah tersebut. Bagi penduduk yang dapat di Islamkan kemudian dibawa ke daerah Rao dan diserahkan tanah (Sjafnir, 1988). Ini merupakan periode pertama, kedatangan mereka kedaerah Pasamanan. Periode kedua, tahun 1930an ketika pemerintah kolonial Belanda membangun sektor perkebunan karet di Pasaman. Seiring dengan pembangunan sektor perkebunan tersebut, maka orang dari Tapanuli Selatan datang ke Pasaman. Periode ketiga, tahun 1950an. Berawal dari permintaan Busyarah Lubis sebagai Bupati Militer Pasaman meminta kepada Bupati Kabupaten Tapanuli Selatan untuk mengirimkan orang Tapanuli ke Pasaman. Busyarah Lubis yang memimpin Kabupaten Pasaman periode Oktober 1947 sampai Desember 1949 adalah orang yang berasal dari keturunan Mandailing itu sendiri.
Sehingga tidaklah heran bila dia menginginkan adanya "keturunan" dia untuk mendiami daerah Pasaman. Bagi pihak Pemerintah Kabupaten Pasaman, kepindahan mereka awalnya dianggap bersifat legal dianjurkan ke daerah Rao. Kedatangan mereka ke Rao sama dengan "menemui sanak saudara" mereka yang sebelumnya telah datang ke Rao.

Rencana untuk memindahkan orang dari Tapanuli Selatan telah dibicarakan oleh pemerinta daerah Kabupaten Pasaman dengan tokoh masyarakat di Rao Mapat Tunggul. Untuk itulah maka tanggal 17 maret 1953, dilakukan penanda tanganan surat perjanjian antara pemerintah daerah Kabupaten Pasaman dengan tokoh masyarakat. Wakil dari pemerintah daerah Bupati dan wakil dari masyarakat yakni ninik mamak Basa nan XV Tanggal 17 Maret 1953, ninik mamak Basa nan XV menyerahkan tanah kosong kepada pemerintah Kabupaten Pasaman dengan beberapa perjanjian.

Namun dalam kenyataannya apa yang telah diikrarkan dalam perjanjian tersebut menurut masyarakat Rao Mapat Tunggul tidak satupun yang ditepati oleh penduduk pendatang. Masyarakat setempat berkalikali menyampaikan hal tersebut kepada pemerintah Kabupaten Pasamaan mengenai keberadaan orang-orang Tapanuli Selatan ini, oleh pihak pemerintah daerah tidak digubris. Mekasudnya pendukung pendatang ke daerah Rao Mapat Tunggul dengan menyeludup (sembunyi-sembunyi) tanpa mematuhi perjanjian yang telah diikrarkan nerupakan suatu bentuk tindakan yang sangat bertentangan dengan isi perjanjian tersebut. Tokoh masyarakat merasa terhina. Sebab penduduk pendatang yang datang tidak ada yang bermusyawarah dengan tokoh masyarakat setempat, seolaholah mereka tidak mendapat penghargaan. Padahal tanah yang ditempati oleh penduduk pendatang adalah tanah ulayat mereka.

Kemudian dalam persoalan agama yang di anut oleh penduduk pendatang. Penduduk asli merasa terkecoh, karena orang diantara penduduk tersebut menganut agama Kristen yang sangat bertentangan sekali dengan agama mereka. Dengan kekecewaaan yang dirasakan oleh penduduk asli, maka pada tanggal 20 Juli 
1956 diadakan rapat bertempat di rumah Jang Dipertuan Padang Nunang mulai pukul 22. 30 sampai 4.00 waktu Indonesia bagian Barat. Rapat tersebut dihadiri oleh Basa nan $\mathrm{XV}$, ninik mamak, alim ulama, imam katib, cadiak pandai, dan lapisan rakyat sewilayah Rao Mapat Tunggul. Adapun agenda rapat tersebut adalah: (1) mengenai status tanah dan hutan diwilayah Rao Mapat Tunggul. (2) status penduduk baru yang datang dari lain daerah. (3) pemeliharaan tata tertib diantara penduduk. Dari acara-acara ini kerapatan telah mengambil keputusan, putusan yang diambil dengan suara bulat sebagai berikut: pertama, membatalkan penyerahan oleh sebagian ninik mamak siwilayah Rao Mapat Tunggul tanah-tanah kosong hutan-hutan pada pemerintah Daerah Kabupaten Pasaman, serta menempati kembali tanah-tanah kosong dan hutan itu dalam statusnya menurut adat yang diadakan di wilayah Rao Mapat Tunggul pada khususnya dan Minangkabau pada umumnya, kedua, Penduduk baru yang berasal dari sesuatu daerah Sumatera Barat maupun yang datang dari propinsi lain yang adat tradisinya berlainan dengan adat yang diadatkan diwilayah Rao Mapat Tunggul, pada khususnya dan Minangkabau pada umumnya ditentukan menurut adat kedaerahannya.

Tegasnya sebagai yang diadatkan, dimana air disauk disana ranting dipatah, dimana negeri dihuni disana adat dituruti. Adapun dalam pemeliharaan tata tertib yakni (1) lebih dahulu mendudukan penduduk baru menurut ketentuan pada pasal diatas. (2) tanah-tanah yang diperoleh mereka dengan jalan yang sah (berketerangan hitam diatas putih) diperkuat oleh rapat untuk mensyahkan hal tersebut. (3) tanah-tanah yang dikerjakan dengan tidak sesuatu keterangan yang sah, maka tanah itu dikembalikan pada kampung/nagari yang mempunyainya menurut adat. Kemudian haruslah dicari penyelesaiannya (perdamaian diantara kampung) negeri dengan orang-orang yang pernah mengerjakan tanah itu. (4) mengingat agama yang dianut oleh rakyat asli keseluruhannya di wilayah Rao Mapat Tunggul, hanya sejenis yaitu Islam, maka penduduk baru yang dapat diterima hanya memeluk Islam. (5) tanah yang statusnya bukan hak milik perseorangan hanya boleh diperjual belikan kalau sepakat diperoleh kedua kaum.

Setelah membahas isi dan syarat penyerahan tanah kosong dan hutan seperti tercantum dalam surat penyerahan pada tanggal 17 Maret 1953, maka rapat berpendapat dan menetapkan bahwa pemerintah daerah Kabupaten Pasaman telah melakukan dua kesalahan yaitu pertama, melanggar/ memperkosa adat yang diadatkan diwilayah Rao Mapat Tunggul yaitu dengan perbuatannya yang tidak sedikitpun mengacuhkan hak Basa nan XV. Terutama dalam usahanya untuk memperoleh kekuasaan pada tanah-tanah kosong dan hutan-hutan yang ada dalam lingkungan hak dari Basa nan XV. Perbuatannya yang memperoleh tanda tangan dari pucuk bulek beberapa kampung, pucuk bulek tersebut adalah sebahagian anggota dari Basa nan $\mathrm{Xv}$, adalah suatu perbuatan adu domba devide at empera. Basa nan Xv menyesali perbuatan pemerintah daerah Kabupaten Pasaman. Kedua, pemerintah daerah Pasaman selain telah melanggar adat yang diadatkan diWilayah Rao Mapat Tunggul. Serta perjanjian tertulis dalam surat penyerahan tanah itu pula satupun yang dipenuhi. Hal ini dapat dibuktikan, beberapa ribu hektar, tanah kosong yang telah dibuka menjadi sawah oleh penduduk baru yang datang dari lain propinsi kewilayah Rao Mapat Tunggul.

Salah satu konflik besar yang pernah terjadi antara etnik Minang dan Mandailing di daerah Pasaman Barat ini tepatnya di daerah Kinali yaitu pada tahun 1987 dimana pada waktu itu sampai melibatkan oknum polisi, tentara dan aparat pemerintah lainnya untuk menyelesaikan masalah tersebut, konflik ini pada dasarnya sangatlah sederhana atau biasa. Konfliknya berawal pada waktu itu dimana seorang anak yang berasal dari etnik Minang menginjak dagangan dari seorang yang beretnik Mandailing, dan si pedagangpun alngsung memukul sang anak dan orang yang melihat kejadian itu pada saat itu adalah orang yang beretnik miang merasa tidak senang melihat kejadian tersebut, dan konflik yang hampir mengarah kepada anarkis dan kekerasanpun hampir pecah pada saat itu tapi akhirnya mampu didamaikan oleh aparat pemerintah. 
Konflik lain yang mengarah kepada anarkisme di daerah Kinali terjadi pada tahun 1999, dimana dalam hal ini pihak yang bertikai adalah etnik maindailing dan etnik Minang. Pada saat itu konflik yang terjadi mengarah kepada anarkisme dimana dalam hal ini pihak yang bertikai membakar pemukiman pihak yang sedang bertindai dengannya. Faktor pemicu terjadinya konflik antara etnik Minang dan etnik Mandailing beragam mulai dari hal kecil seperti bercanda-canda diwarung, anak-anak yang bertengkar, tidak bertegur sapa, hasil panen, harga dagangan yang mahal, dan hal-hal sepele lainnya bisa berujung kepada konflik dan bahkan bisa menjadi konflik besar yang mana melibatkan pihak-pihak yang dituakan untuk menyelesaikannya.

\section{KONFLIK KINALI 1999-2010}

Konflik-konflik kecil antara etnik Minang dan etnik Mandailing banyak terjadi di daerah Pasaman dan Kinali khususnya dan bahkan dapat dikatakan sering penyebabnya mungkin hanya karena hal sepele tapi hal spele tadi bisa berujung pertikaian dan memunculkan konflik besar yang berujung anarkis. Konflik yang terjadi pada tahun 1999 dimulai dari maslaah yang bisa dikatan sangat sepele bermula dari bercanda-canda diwarung anatara beberap pemuda yng akhirnya berujung kepada kesalahpahaman yang memunculkan pertengkaran. Pemuda-pemuda yang bertikai tadi menyampaikan pertengkaran yang terjadi ke saudara dan keluarga mereka dimana setelah mendengar cerita tersebut kolega dari etnik yang sama denagn pemuda tersebut merasa tidak senang karena sodara mereka dari sesama etnik diganggu yang mana akhirnya berujung kepada konflik besar antar etnik.

Masyarakat dari etnik yang bertikai yaitu etnik Minang dan etnik Mandailing, hidup dalam ke was-wasan pada saat itu, seolah-olah mereka akan terbawa-bawa dalam konflik yang terjadi diantara kedua etnik tersebut akibatnya dinding pemisah antara kedua etnik semakin ketara. Hal ini berkelanjutan meskipun konflik yang terjadi sudah diselesaikan dengan jalan negosiasi mengenai solusi penyelesaian pertikaian yang ditengahi oleh mediator, tetapi masyarakat dari etnik yang bertikai tetap saling menjaga jarak, seolah-olah tidak mau membaur dengan etnik lain, adapun sosialisasi yang dilakukan hanya dalam bentuk formaldan pemenuhan kebutuhan seperti di tempat kerja dan di pasar.

Munculnya dinding pemisah diantara kedua etnik yang bertikai ini berlangsung cukup lama. Pada tahun 2000 sampai dengan 2007 etnik yang bertikai masih saling menjaga jarak akibatnya keselarasan dan keharmonisan sesama warga tidak terjadi, mereka masih hidup saling berkelompok dengan etnik masing-masing dan bahkan pertikaian-pertikaian kecil antara kedua etnik masih terjadi tetapi tidak mengarah kepada konflik besar. Pertikaianpertikaian kecil antara kedua etnik yang sering terjadi itu kebanyakan penyelesaiannya dimana salah satu pihak mengalah atau memilih untuk tidak merespon atau memperpanjang masalah yang terjadi. Mengalahnya salah satu pihak tidak menyebabkan etnik tersebut hidup dalam keharmonisan malahan membentuk dinding pemisah yang sangat jelas dimana mereka mimilih untuk tidak berbaur dengan etnik yang lain guna untuk menghindari menculnya konflik antar etnik. Pada tahun2008 etnik yang bertikai mulai sadar dan merekapun mulai mencoba menghilangkan dinding pemisah diantara kedua etnik tersebut dan hal ini berkelanjutan hingga sekarang.

Pada saat sekarang ini etnik Minang dan Mandailing sudah mulai membentuk suatu keselarasan dan keharmonisan dalam bersosialisai dengan etnik-etnik yang ada di Kinali, hal ini dapat dilihat dari sifat gotong royong yang mereka lakukan. Etnik yang dulunya bertikai sudah mulai bergotong royong bantu membantu dalam hal yang bersifat umum dan bahkan yang bersifat khusus. Contohnya jika ada acara kerja bakti ataupun gotong royong misalkan di masjid, etnik Mandailing juga ikut membantu, dan misalkna etnik Mandailing ada membuat acara atau kenduri mereka mereka juga mengudang etnik Minang untuk menghadiri acara mereka.

Konflik yang terjadi antara etnik Minang dan Mandailing di Kinali pada tahun 1999 memunculkan dinding pemisah antara kedua etnik yang cukup lama, tetapi semakin majunya jaman pola berpikir masyarakatpun semakin berkembang 
karena ada hal-hal yang lebih penting dari pada memicu untuk menimbulkan konflik. Mereka mulai sadar bahwa dampak dari konflik akan menyisakan trauma dan kerugian kepada kedua etnik yang bertikai kesimpulannya tidak ada yang etnik yang beruntung dari knflik yang terjadi yang ada hanya rasa kewas-wasan dan spekulasispekulasi negatif.

Pada saat sekarang ini masing-masing etnik yang bertikai dulunya, kini saling mencoba untuk menjaga keharmonisan dengan etnik yang lain, hal ini dapat penulis katahui dari hasil wawancara dengan beberapa penduduk terlebih dari etnik Mandailing, dimana ketika penulis mewawancarai mengenai kronologis konflik yang terjadi pada tahun 1999 kebanyakan dari mereka mengatakan bahwa konflik yang terjadi adalah konflik perselisihan antar kampung dan bukan perselisihan atas etnik, dan bahkan ada juga yng tiadak mau menceritakan nya karena mereka takut akan menimbulkan salah persepsi pada etnis lain. Kesimpilannya mereka tidak mau terlalu banyak beragumen karena takut nanti akan menimbulkan kesalahpahaman dengan etnik lain karena hasil dari konflik adalah kerugian baik itu materi ataupun rohani mereka (wawancara dengan Bapak Damanuri pada tanggal 3 maret 201216.00 WIB).

\section{FAKTOR PENYEBAB KONFLIK.}

\section{Faktor Sosial Budaya}

Identitas sosial berbagai suku bangsa di Indonesia lengket kepada suatu wilayah. Inilah yang disebut dengan ethoterritorialism, wilayah etnis (Afrizal, 2012). Ikatan primodial pada dasarnya berakar pada identitas dasar yang dimiliki oleh para anggota suatu kelompok etnik, seperti tubuh, nama, bahasa, agama atau kepercayaan, sejarah dan asal usul. Identitas dasar ini merupakan sumber acuan bagi para anggota suatu kelompok etnik dalam melakukan interaksi sosialnya. Oleh karena itu, identitas dasar merupakan suatu acuan yang sangat mendasar dan bersifat umum, serta menjadi kaerangka dasar bagi perwujudan suatu kelompok etnik. Identitas dasar diperoleh secara askriptif dan tidak mudah untuk mengingkarinya, identitas dasar muncul dalam interaksi sosial antara kelompok etnik.

Konflik yang terjadi di tahun 1999 saat itu antara etnik Mandailing dan etnik Minang, dimana pihak yang bertikai saling membakar rumah-rumah pihak yang menjadi lawan mereka, dan bahkan rumah ibadahpun sampai dibakarnya. Konflik yang muncul hanya didasarkan kepada kesalahpahaman semata tetapi karena ketidak senangan kepada etnik lain karena sejarah panjang dari ketidak senangan antar etnik yang beretikai tadi menyebabkan konflik yang seharusnya bisa diselesaikan oleh mereka yang bertikai tanpa harus membawa pihak lain yang berujung kepada konflik besar.

Berujungnya konflik kecil menjadi konflik besar dikarenakan ikatan emosional antar etnis yang memiliki identitas dasar yang sama sehingga rasa tidak terima dan akan perlakuan dari etnik lain kepada etnik mereka membuat mereka mau terlibat untuk membela etnik dari kelompok mereka dalam konflik yang terjadi. Dari dua orang yang bertikai dari etnik yang berbeda, menjadi 10 orang dari 10 orang menjadi banyak yang akhirnya konflik besarpun pecah menjadi konflik antar etnik.

\section{Faktor Sosial Ekonomi}

Mata pencaharian yang bersumber dari perkebunan tanaman tua, menghendaki lahan yang luas. Kebutuhan akan lahan yang luas tersebut menjadikan masyarakat pada masa lampau merambah hutan sebagai lahan baru (Firdaus, 2012). Masuknya perkebunan kelapa sawit ke kecamatan Kinali telah membawa sejumlah perubahan sosial budaya bagi masyarakat. Bentuk-bentuk dan proses perubahan terjadi dalam berbagai bidang kehidupan seperti, perubahan system pertanian yang semula masih bersifat subsistensi menjadi komersial.demikian juga dengan semakin berkembangnya berbagai usaha ekonomi non-pertanian (off-farm) dan wilayah perdesaan.

Salah satu persoalan yang banyak mengemukakan dengan adanya 
pembukaan kebun kelapa sawit baik oleh pihak PT maupun oleh masyarakat sendiri adalah masalah seputar penguasaan dan kepemilikan tanah. Tanah-tanah ulayat yang semula hanya lahan yang tidak produktif kini memiliki nilai ekonomi yang tinggi. Masalah lain yang juga lazim muncul adalah kepemilikan kavling kebun plasma yang bersifat ganda atau justru bersifat fiktif. Salah satu penyebab adalah karena dimasukkannya beberapa nama anggota yang bukan penduduk setempat, tentu saja menurut ketentuan mereka tidak berhak. Ada juga beberapa lahan yang semula dimaksudkan sebagai kebun plasma oleh pihak PT, setelah sekian tahun berjalan dan sawit tersebut sudah menghasilkan ternyata belum juga diserahkan kepada anggota masyarakat.

Salah satu persoalan yang banyak mengemukakan dengan adanya pembukaan kebun kelapa sawit baik oleh pihak PT maupun oleh masyarakat sendiri adalah masalah seputar penguasaan dan kepemilikan tanah. Tanah-tanah ulayat yang semula hanya lahan yang tidak produktif kini memiliki nilai ekonomi yang tinggi menyebabkan banyak pihak merasa berhak atas penguasaan dan kepemilikannya. Dalam hal ini masyarakat etnik Minang mengaku sebagai penduduk asli tidak suka melihat etnik lain memiliki lahan sawit yang mana menurut mereka itu adalah tanah ulayat mereka. Dalam hal ini kecemburuan sosialpun muncul yang mana dapat memicu terjadinya konflik antar etnik.

Perbenturan yang terjadi karena persolan ekonomi dalam hal ini tanah memang merupakan suatu gejala yang bukan saja sekarang ini terjadi namun sudah lama merasuki kehidupan masyarakat kita. Gejala tersebut muncul tidak terlepas dari fungsi tanah itu sendiri. Bagi masyarakat Minangkabau misaknya, tanah bukan saja berfungsi sebagai tempat tinggal, sumber produksi atau pendapatan, tetapi juga mempunyai fungsi sosial dimana dengan tanah tersebut dapat mencerminkan kedudukan sosial dan status seseorang ditengah masyarakat atau dengan kata lain tanah sebagai dasar dari perbedaan sosial di dalam masyarakat.

Begitu pentingnya tanah ini didalam kehidupan masyarakat Minangkabau, sehingga tidaklah mengherankan seringnya muncul permasalahan seperti dalam hal kepemilikan tanah itu sendiri. Oleh karena itulah etnik Minangkabau sebagai penduduk asli menganggap etnik Mandailing telah merebut hak milik mereka atas tanah yang ada di daerahnya. Dalam perebutan tanah tersebut konflik yang mengarah kebentuk kekerasanpun terjadi.

\section{Faktor Sosial Politik}

Salah satu hal yang menyebabkan masuknya etnik Mandailing ke Pasaman adalah karena permintaan dari Bupati Pasaman kepada Bupati Tapanuli untuk mengirimkan orang Tapanuli ke Pasaman Pada Tahun 1950an. Busyarah Lubis yang sebagai Bupati Militer Pasaman pada saat itu meminta kepada Bupati Kabupaten Tapanuli Selatan untuk mengirimkan orang Tapanuli ke Pasaman. Busyarah Lubis yang memimpin Kabupaten Pasaman periode Oktober 1947 sampai Desember 1949 adalah orang yang berasal dari keturunan Mandailing itu sendiri. Bagi pihak Pemerintah Kabupaten Pasaman, perpindahan etnik Mandailing pada awalnya dianggap bersifat legal dianjurkan kedaerah rao.

Rencana untuk memindahkan orang dari Tapanuli Selatan telah dibicarakan oleh pemerintah daerah Kabupaten Pasaman dengan tokoh masyarakat di Rao Mapat Tunggul. Ninik mamak Basa nan XV menyetujui keinginan dari pemerintah tadi, dan ninik mamak Basa nan XV menyerahkan tanah kosong kepada pemerintah Kabupaten Pasaman dengan beberapa perjanjian, yakni: pertama, dalam pembagian tanah itu hendaklah lebih didahulukan rakyat yang berasal dari wilayah Rao Mapat Tunggul. Kedua, orang yang diberi tanah hendaklah disaring benar-benar oleh pemerintah daerah Kabupaten Pasaman, serta negeri dimana mereka berdiam dinegeri itulah mereka menurut adat istiadat. Ketiga, untuk menentukan tanah-tanah kosong dan membagikan 
tanah itu mestinya pemerintah daerah Kabupaten Pasaman bekerja sama dengan komisi yang ditunjukkan oleh kerapatan daerah wilayah Rao Mapat Tunggul. Keempat, manakala untuk pembangunan nantinya, merusak hak milik rakyat hendaklah pemerintah mengadakan ganti rugi. Namun dalam kenyataanya apa yang telah diikrarkan dalam perjanjian tersebut menurut masyarakat Rao Mapat tunggul tidak satupun yang ditepati oleh penduduk pendatang. Masyarakat setempat berkali-kali menyampaikan hal tersebut kepada Pemerintah Kabupaten Pasaman mengenai keberadaan orang Tapanuli Selatan ini, oleh pihak pemerintah daerah tidak digubris.

Masuknya penduduk pendatang ke daerah Rao Mapat Tunggul dengan menyeludup tanpa mematuhi perjanjian yang telah diikrarkan merupakan suatu bentuk tindakan yang sangat bertentangan denga perjanjian tersebut. Tokoh masyarakat merasa sangat terhina. Sebab penduduk pendatang yang tidak ada yang bermusyawarah dengan tokoh masyarakat setempat, seolah0olah mereka tidak mendapat penghargaan. Padahal tanah yang di tempati oleh penduduk pendatang adalah tanah ulayat mereka. Dan penduduk aslipun merasa kecewa dengan keadaan yang terjadi. Dengan kekecewaan yang dirasakan oleh penduduk asli, maka pada tanggal 20 Juli 1956 diadakan rapat bertempat dirumah Jang dipertemuan Padang Nunang. Rapat tersebut dihadiri oleh Basa nan Xv, ninik mamak, alim ulama, imam katib, cadiak pandai, dan lapisan rakyat sewilayah rao Mapat Tunggul. Dari rapat yang diadakan itu ninim mamak mengambil keputusan yaitu membatalkan penyerahan lahan kosong kepada pemerintah daerah Kabipaten Pasaman, penduduk baru yang berasal diminta untuk mengikuti adat istiadat yang berlaku di Pasaman

\section{DAMPAK SOSIAL KONFLIK TERHADAP MASYARAKAT.}

\section{Dampat Sosial Budaya}

Dampak dari konflik yang terjadi itu masyarakat hidup dalam kecemasan dan ke was-wasan mereka takut suatu waktu akan diserang atau dibawa-bawa kedalam konflik tersebut. Untuk menghindari supaya mereka tidak terlibat dalam konflik yang terjadi pada etnik mereka itu maka mereka lebih meilih untuk diam dirumah, dan mereka mengurangi dan bahkan sampai tidak melaksanakan aktifitas dan rutinitas yang biasa mereka lakukan seperti pergi kekebun, bekerja ke pasar dan bahkan anak-anak emrekapun dilarang untuk pergi kesekolah (wawancara dengan Bapak rusdi).

Rasa ketakutan dan was-was yang dilakukan oleh masyarakat tersebut berlangsung cukup lam sampai suasana benar-benar sudah aman menurut mereka meski walaupun kedua belah pihak yang bertikai yaitu etnik Minang dan etnik Mandailing sudah di damaikan oleh pihak yang berwajib dan pemuka adat dan nagari mereka dalam hal ini masyaraakat yang tidaka mau terlibat masih merasa was-was. Bahkan untuk menghindari konflik masyarakat yang berada di lingkungan tempat rumahrumah yang dibakar oleh etnik yang bertikai tersebut, mereka lebih memilih untuk pindah dari pada tetap bertahan disana dan ikut terbawa kedalam perselisihan yang terjadi pada kedua etnik tersebut.

\section{Dampak Terhadap Sosial Ekonomi}

Dampak dari konflik yang terjadi tidak hanya berdampak kepada sosial masyarakat tetapi pada ekonomi masyarakat juga. Dalam hal ini karena rasa was-was dan ketakuatn tadi masyarakat lebih meilih untuk tinggal berdiam diri dirumah dari pada melaksanakan aktifitas mereka. Otomatis dalam hal ini perekonomian masyarakat pun jadi terganggu karena semuanya saling berhubungan. Contohnya masyarakat jadi takut kekebun atau keladang sehingga tidak ada penghasilan atau upah kepada buruh atau petani yang tidak bekerja, rutinitas dalam penggarapan kebun dan ladangpun menjadi terhenti, pengiriman hasil penenpun menjadi terganggu, dpata dikatan semuanya jadi saling berhubungan tidak ada aktifitas untuk 
perkebunan dan ladang maka pemasukan untuk pendapatan pun tidak ada.

Tidak hanya pada petani, pekerja, buruh dan pemilik lahan dan perkebunan dampak dari konflik ini juga berpengaruh kepada rutinitas di pasar dimana seharusnya pasar adalah merupakan tempat bertemunya antara penjual dan pembeli untuk melakukan transaksi guna memenuhi kebutuhan mereka jadi terhambat yang ada hanya beberapa pedagang yang cukup memberanikan diri untuk membuka usahanya ditengah konflik yang cukup terjadi sedangkan konsumen atau masyarakat yang belanja pun sangatlah sedikit. Hal ini cukup berdampak kepada kehidupan perekonomian masyarakat karena aktifitas masyarakat untuk menghasilkan dan menjadi produktif terhambat oleh konflik yang terjadi pada saat itu.

\section{Dampak Terhadap Sosial Politik}

Pada tahun 1950an Bupati Militer Pasaman meminta kepada Bupati Kabupaten Tapanuli Selatan untuk mengirimkan orang Tapanuli ke Pasaman, dimana bupati Pasaman pada saat itu berasal dari keturunan Mandailing dan ia menginginkan adanya "keturunannya" untuk mendiami daerah Pasaman. Awal perpindhan etnik Mandailing di anggap bersifat legal karena rencana untuk memindahkan orang dari Tapanuli Selatan telah dibicarakan oleh pemerintah daerah Kabupaten Pasaman dengan tokoh masyarakat di Rao Mapat Tunggul. Tokoh masyarakat menyetujui apa yang diminta oleh Bupati Pasaman tersebut dengan beberapa syarat yang ditetapkan.

Tetapi apa yang telah diikrarkan dalam perjanjian tersebut tidak satupun ditepati oleh penduduk pendatang. Masyarakat setempat berkali-kali menyampaikan hal tersebut kepada pemerintah Kabupaten Pasaman mengenai keberadaan orang Tapanuli selatan ini, oleh pihak pemerintah daerah tidak di gubris. Dengan kekecewaaan yang dirasakan oleh penduduk asli, masyarakat berpendapat dan menetapkan bahwa pemerintah daerah Kabupaten Pasaman telah melakukan dua kesalahan yaitu pertama, melanggar/ memperkosa adat yang diadatkan diwilayah Rao Mapat Tunggul yaitu dengan perbuatannya tidak sedikitpun mengacuhkan hak Basa nan XV. Kedua, pemerintah daerah Pasaman selain telah melanggar adat yang diadatkan diwilayah Rao Mapat tunggul. Serta perjanjian tertulis dalam surat penyerahan tanah itu pula tidak satupun dipenuhi.

\section{RESOLUSI KONFLIK DI KECAMATAN KINALI}

Sebagai sebuah konflik di suatu sisi telah merusak tatanan kehidupan diantara etnik, namun disisi lain telah mengokohkan keberadaan lembaga adat di daerha tersebut, yakni perannya dalam menyelesaikan konflik tersebut. Lembaga adat ini "terpakai" disamping ada legitimasi oleh pemerintah dalam menggunakan jalur adat dalam menyelesaikan konflik juga keengganan masyarakat untuk menempuh jalur pengadilan negeri baik alasan prosedurnya maupun masalah biayanya serta mereka tidak akrab dengan hal tersebut, mereka menganggap hal tersebut sebagai "dunia baru" dalam proses penyelesaian suatu maslah.

Merangkai konflik untu memecahkannya dengan cara musyawarah menuju mufakat dengan menggunakan lembaga adat adalah merupakan hal yang selalu melekat dalam diri masyarakat Minangkabau. Dalam masyarakat Minangkabau, konflik dipandang sebagai suatu yang penting untuk mencapai suatu persatuan dalam masyarakat. Oleh sebab itu suatu konflik yang terjadi ada aturan dan sistem sosial yang mengaturnya. Lembaga adat tersebut adalah KAN. Tiap nagari di perintah oleh KAN masing-masing. Posisi lembaga adat dalam menyelesaikan konflik pun mendapat pengakuan dari pemerintah. Bahkan ada semacam legitimasi secara formal oleh pemerintah untuk mengakui keberadaan hukum adat setempat dalam menyelesaikan masalah konflik, misalnya tanah.

Semua persoalan diantara nagari pada pokoknya di putuskan oleh pemerintah nagari lewat lembaga adat. Lembaga- 
lembaga adat baru mendapatkan pengakuan dan statusnya sebagai hakim pedamaian. Pribumi tidak dihalangi untuk menyampaikan perkara mereka ke pengadilan, namun harus menerangkan kepada mereka apakah "peradilan kampung" telah memberikan keputusan dalam kasus tersebut, dan jika demikian mereka wajib mempertimbangkan keputusan tersebut. Itupula sebabnya ketika terjadi konflik tahun 1999 dimana penduduk asli tidak senang atas kehadiran penduduk pendatang ini.

\section{KESIMPULAN}

Konflik antar etnik Minang dan Mandailing di Kecamatan Kinali Pasaman Barat dimulai dari kedatangan etnik Mandailing ke daerah Pasaman. Etnik Minang sebagai penduduk asli menganggap etnik Mandailing telah merebut hak milik mereka atas tanah yang ada di daerahnya. Rasa tidak suka akan etnik Mandailing berlanjut hingga sekarang. Sikap orang etnik Mandailing yang tidak adaptif dalam pola hubungannya dengan kebudayaan dominan yang ada di Kinali disebabkan oleh sikap diskriminatif etnik Minang di Kinali terhadap etnik Mandailing dalam berbagai segi kehidupan yang mereka jalani selama ini yang akhirnya berbuah keengganan untuk membaur dan bergaul secara normal dan wajar dengan etnik lain dikecamatan Kinali sehingga akibatnya seringkali terjadi perselisishan antara kedua etnik tersebut.

Faktor-faktor yang mendorong terjadinya konflik di Kecamatan Kinali Pasaman Barat adalah: pertama, dilihat dari faktor sosial budaya yaitu identitas dasar yang menjadi suatu pembeda antara berbagai kelompok etnik yang sedang berinteraksi. Hal inilah yang memicu terjadinya konflik di Kinali Pasaman Barat dari hal sepel yang akhirnya berujung anarkis adalah dikarenakan rasa ketidaksukaan akan etnik lain yang mengganggu atau melecehkan etnik mereka. Kedua, dilihat dari faktor sosial ekonomi adalah adanya pembukaan kebun kelapa sawit baik oleh pihak PT maupun oleh masyarakat sendiri dan yang menjadi masalah adalah seputar penguasaan dan kepemilikan tanah. Ketiga, dilihat dari faktor sosial politik yaitu masuknya etnik Mandailing ke Pasaman karena permintaan dari Bupati Pasaman kepada Bupati Tapanuli untuk mengirimkan orang tapanuli ke Pasaman pada tahun 1950an.

Konflik yang terjadi antara etnik Minang dan Mandailing di Kinali pada tahun 1999 memunculkan dinding pemisah antara kedua etnik yang berlangsung dalam kurun waktu yang cukup lama akibatnya keselarasan dan keharmonisan sesama warga tidak terjadi dimana mereka masih hidup saling berkelompok dengan etnik masing-masing dan bahkan pertikaianpertikaian kecil antara kedua etnik masih terjadi. Pada saat sekarang ini masingmasing etnik yang bertikai dulunya, kini saling mencoba untuk menjaga keharmonisan dengan etnik yang lain, dimana mereka sudah mulai mencoba menghilangkan dinding pemidah diantara kedua etnik tersebut hal ini dapat dilihat dari sifat gotong royong yang dilakukan oleh kedua etnik tersebut.

Dampak dari konflik di Kecamatan Kinali Pasaman Barat terhadap masyarakat dilihat dari: pertama, dari faktor sosial budaya yaitu pemilik identitas dasar yang sama dengan etnik yang sedang bertikai terbawa-bawa dalam konflik tersebut, dan sedangkan yang tidak mau terlibat. Kedua, dari faktor sosial ekonomi, konflik berdampak kepada terjadinya penurunan penghasilan masyarakat dan daerah karena pasca konflik masyarakat memilih untuk tidak berinteraksi dan salah satunya tidak ke pasar dan juga tidak pergi bekerja dan anak-anakpun juga dilarang untuk pergi sekolah. Ketiga, dari faktor sosial politik yaitu rasa kecewa yang dirasakan oleh penduduk asli terhadap pemerintah daerah Kabupaten Pasaman karena tidak menepati perjanji yang tertulis dalam surat penyerahan tanah kepada etnik Mandailing. Didalam pemikiran etnik Minang mereka merasa etnik Mandailing ini telah membohongi dan menipu mereka sebagai masyarakat asli dari daerah Pasaman ini dan dari sinilah muncul semacam ketidaksukaan atas etnis Mandailing hal itu berlangsung sampai dengan sekarang.

\section{DAFTAR PUSTAKA}

Afrizal, A. (2012). Kontestasi Ruang; Tinjauan Sosiologis Keadilan Ekologis. Jurnal Ilmu Sosial Mamangan, 1(1), 111. 
Asnan, G. (2003). Kamus Sejarah Minangkabau. Padang: Pusat Pengkajian Islam dan Minangkabau (PPIM).

Firdaus, F. (2012). Puar Cama Untuk Anak Cucu: Kearifan Lokal Untuk Sustainability Forest di Manggarai Barat. Jurnal Ilmu Sosial Mamangan, 1(1), 39-50.
Mansoer, M. . (1970). Sedjarah minang kabau. Jakarta: Bhratara.

Sjafnir, A. N. (1988). Tuanku Imam Bonjol: Sejarah Intelektual Islam di Minangkabau. Padang: Esa.

Sjahmunir. (2001). Status Wanita Dalam Kepemilikan Tanah Ulayat di Minangkabau. Padang. 
